\title{
Rancang Bangun Sistem Informasi Pembuatan Peraturan Perusahaan (3P) Pada Dinas Tenaga Kerja Kota Samarinda Dengan Metode Rapid Application Development
}

\author{
Sri Rahayu Natasia ${ }^{1 *}$, Brianto Rovi Harjanto ${ }^{2}$, Ariyadi $^{3}$ \\ ${ }^{1,2}$ Program Studi Sistem Informasi, Institut Teknologi Kalimantan, Balikpapan, Kalimantan Timur \\ ${ }^{3}$ Program Studi Informatika, Institut Teknologi Kalimantan, Balikpapan, Kalimantan Timur \\ Email: ${ }^{1 *}$ natasia.ayu@ @lecturer.itk.ac.id, ${ }^{2} 10171012 @$ student.itk.ac.id, ${ }^{3}$ ariyadi@lecturer.itk.ac.id
}

(Naskah masuk: 31 Des 2020, direvisi: 2 Feb 2021, diterima: 4 Feb 2021)

\begin{abstract}
Abstrak
Dinas Tenaga Kerja (DISNAKER) Kota Samarinda merupakan salah satu Organisasi Perangkat Daerah (OPD) yang bertugas untuk melayani masyarakat pada bidangnya. Salah satu layanan di DISNAKER yaitu pembuatan peraturan perusahaan, dimana proses pembuatannya masih secara manual. Diawali perusahaan membawa berkas-berkas yang diperlukan ke DISNAKER, kemudian perusahaan menunggu sekitar 3-4 hari atau bahkan lebih yang dikarenakan tertumpuknya berkas-berkas. Jika dikabarkan kekurangan berkas atau revisi, maka perusahaan tersebut perlu melengkapi atau merevisi dan memberikan kembali ke DISNAKER. Hal ini tentunya membutuhkan waktu yang lama dalam proses pembuatan peraturan perusahaan. Oleh karena itu, dilakukan penelitian untuk merancang dan membangun Sistem Informasi Pembuatan Peraturan Perusahaan (3P) berbasis website dengan menggunakan metode Rapid Application Development (RAD). Metode RAD memiliki 4 fase dalam pembangunan sistem yaitu, fase perencanaan syarat-syarat, fase desain pengguna, fase konstruksi, dan fase pelaksana. Sistem yang telah dibuat berhasil membuat surat keputusan sesuai dengan perusahaan yang mengajukan, dimana surat keputusan merupakan surat yang menyatakan peraturan perusahaan tersebut telah disetujui. Dengan demikian sistem ini diharapkan dapat membantu perusahaan dalam pembuatan peraturan perusahaan tanpa datang ke DISNAKER dan mengurangi biaya mencetak berkas serta dapat membantu DISNAKER mempercepat pembuatan peraturan perusahaan.
\end{abstract}

Kata Kunci: DISNAKER, Rapid Application Development, Sistem Informasi, Peraturan Perusahaan.

\section{Designing and Developing Information System of Company Regulations Production (3P) for Samarinda City Labor Office Using Rapid Application Development Method}

\begin{abstract}
Samarinda City Labor Office (DISNAKER) Kota Samarinda is one of the regional apparatus organization (OPD) whose job is to serve public people in its field. One of the services at DISNAKER is making company regulations, where the process is still manual. Initialy the company brought documents to DISNAKER, then the company waited for 3-4 days or more due to the pilling up of files. If the company get reported there is a lack of files or revisions, the company needs to complete or revise and give back to DISNAKER. This process of making company regulations requires a long time. Therefore, research was carried out to design and build a website-based Information System of Company Regulations Prodcution (3P) for Samarinda City Labor Offices using Rapid Application Development (RAD) method. The RAD method has 4 phases in system development, the requirements planning phase, the user design phase, the construction phase, and the implementation phase. The system has succeeded in making a decision letter according to the submitting company, where the decision letter is a letter that the company regulations have been approved. This system is expected can help companies in making regulations without coming to DISNAKER and reduce the cost of printing files and can help DISNAKER accelerate the making of company regulations.
\end{abstract}

Keywords: DISNAKER, Rapid Application Development, Information System, Company Regulations. 


\section{PENDAhuluan}

Seiring berkembangnya zaman, perkembangan teknologi informasi semakin pesat di era globalisasi saat ini. Penerapan teknologi informasi umumnya dapat dijumpai pada suatu perusahaan atau organisasi pemerintahan berskala kecil maupun besar. Pada saat ini, kinerja organisasi sangat dipengaruhi oleh penguasaan teknologi informasi dari karyawan suatu organisasi. Dengan adanya teknologi, suatu organisasi akan mengalami perubahan sistem manajemen dari tradisional ke kontemporer [1]. Surat menyurat, administrasi keuangan, dan administrasi laporan adalah contoh dari penerapan aplikasi dari suatu organisasi pemerintahan. Pemanfaatan Teknologi Informasi dan Komunikasi (TIK) dalam suatu aplikasi membutuhkan infrastruktur hardware, jaringan internet, pengadaan, software dan lain sebagainya [2]. Oleh karena itu, lingkungan teknologi memungkinkan perusahaan atau organisasi meningkatkan kinerja pegawai TI yang akan menumbuhkan hubungan yang saling menguntungkan [3].

Adapun penelitian yang dilakukan oleh Amalia \& Nurul telah berhasil membantu instansi atau dinas dengan menggunakan teknologi untuk mempercepat kinerja. Penelitian ini melakukan pembuatan sistem informasi pengarsipan surat masuk dan keluar berbasis website pada Dinas Sosial Tenaga Kerja dan Transmigrasi di Musi Bayuasin. Pengembangan sistem informasi ini menggunakan metode Rapid Application Development (RAD). Metode RAD memungkinkan pengembangan sistem menjadi lebih cepat serta developer atau pengembang langsung bertemu dengan stakeholder sehingga dapat berdiskusi langsung apabila desain ataupun fitur masih kurang sesuai dengan keinginan stakeholder. Selain itu, desain database, fitur, dan antarmuka dapat digunakan oleh pengembang selanjutnya untuk memperbaiki atau menambahkan fitur yang belum ada [4]. Dengan menggunakan metode RAD, penelitian Amalia \& Nurul berhasil membuat sistem informasi pengarsipan surat masuk dan keluar sehingga memudahkan pegawai dalam pengolahan data surat, laporan surat dan disposisi surat pada Dinas Sosial Tenaga Kerja dan Transmigrasi di Musi Bayuasin [5].

Dinas Tenaga Kerja (DISNAKER) Kota Samarinda merupakan dinas yang membantu walikota melaksanakan urusan pemerintahan dibidang tenaga kerja dan transmigrasi yang meliputi penempatan tenaga kerja dan perluasan kerja, pelatihan dan produktivitas tenaga kerja, hubungan industrial dan persyaratan [6]. DISNAKER juga menggunakan teknologi informasi pada kegiatan operasional pegawai. Namun, tidak semua kegiatan operasional pegawai telah diakomodasi oleh teknologi informasi. Salah satunya yaitu proses pembuatan peraturan perusahaan pada DISNAKER Kota Samarinda. Sebelum membuat peraturan perusahaan, suatu perusahaan tersebut harus membawa surat permohonan dan draf peraturan perusahaan kepada bagian Sekretariat untuk diseleksi dan dibuat surat disposisi ke bidang Hubungan Industrial \& Persyaratan Kerja (HI\&SYAKER). Kepala Bidang HI\&SYAKER akan mempelajari berkas tersebut, setelah itu berkas tersebut diberikan kepada Kepala Seksi HI\&SYAKER untuk memeriksa kelengkapan berkas. Jika berkas sudah lengkap maka Teknis akan mempelajari dan memeriksa draf peraturan perusahaan. Kemudian Teknis akan mencetak surat keputusan yang akan diparaf oleh Kepala Seksi HI\&SYAKER, Kepala Bidang HI\&SYAKER, dan Sekretaris serta ditandatangani oleh Kepala Dinas Tenaga Kerja. Setelah itu draf peraturan perusahaan dan surat keputusan akan diberikan kepada perusahaan. Hal ini tentunya membutuhkan waktu yang cukup lama dalam proses pembuatan peraturan perusahaan yang melalui banyak proses. Selain itu, adanya human error yang memungkinkan terjadi dalam proses pembuatan peraturan perusahaan yang masih berbasis kertas dan manual.

Oleh karena itu, dilakukan penelitian di DISNAKER Kota Samarinda yaitu merancang dan membangun Sistem Informasi Peraturan Perusahaan berbasis website dengan menggunakan metode RAD. Sistem informasi ini akan memudahkan DISNAKER Kota Samarinda khususnya pada bidang HI\&SYAKER dalam pembuatan peraturan perusahaan secara digital. Selain itu, perusahaan juga akan terbantu dengan sistem ini dari segi waktu dan biaya. Dengan diadakannya penelitian ini, diharapkan sistem informasi yang akan dibangun dapat berdampak positif untuk DISNAKER Kota Samarinda.

\section{METODOLOGI PENELITIAN}

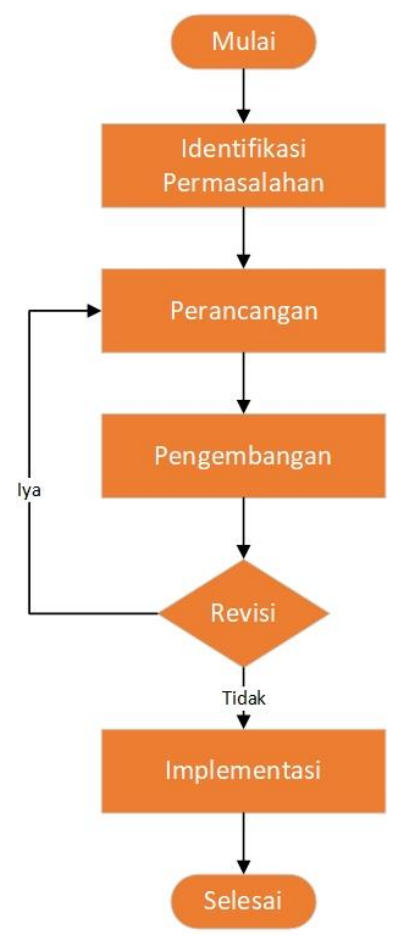

Gambar 1. Metodologi Penelitian

Prosedur penelitian adalah langkah-langkah yang ditempuh dalam melakukan penelitian. Penelitian ini mengadaptasi kerangka kerja Rapid Application Development 
(RAD) untuk membangun aplikasi Sistem Informasi Pembuatan Peraturan Perusahaan berbasis website pada DISNAKER Kota Samarinda. Menurut MC Leod (2002), RAD adalah proses model perangkat lunak yang menekankan siklus pengembangan yang singkat. Adapun fase-fase yang dilakukan pada metode RAD yaitu fase perencanaan kebutuhan, fase perancangan desain, fase pengembangan, dan fase implementasi. Model RAD menggunakan pendekatan kontruksi berbasis komponen, jika setiap kebutuhan dan batasan ruang lingkup projek telah diketahui memungkinkan tim pengembang untuk membuat sebuah sistem dalam jangka waktu yang singkat [7]. Adapun metodologi penelitian yang telah dibuat dengan metode RAD sebagai referensinya. Perbedaan antara metodologi penelitian dan metode RAD yaitu dari segi penamaan, dimana tiap tahapan pada metodologi penelitian sama dengan metode RAD. Gambar 1 merupakan metodologi penelitian yang digunakan.

\section{A. Identifikasi Permasalahan}

Pada tahap ini, dilakukan identifikasi alur prosedur yang sedang berjalan, identifikasi kelemahan alur prosedur yang sedang berjalan, dan memberikan solusi. Berdasarkan hasil wawancara dengan stakeholder seperti kepala seksi dan teknis bidang HI\&SYAKER terkait kebutuhan sistem yang akan dibangun, kemudian melakukan analisis kebutuhan sistem dengan membuat activity diagram [8] dan rumusan masalah dari sistem yang sedang berjalan. Setelah itu, memberikan solusi terhadap rumusan masalah yang telah dibuat.

\section{B. Perancangan}

Pada tahap ini, dilakukan perancangan yaitu prosesproses yang akan dilakukan pada sistem. Perancangan yang dilakukan seperti perancangan fungsionalitas sistem dengan menggunakan salah satu diagram dari Unified Modeling Language (UML) yaitu use case diagram [8], perancangan basis data dengan menggunakan Entity Relationship Diagram [9], dan perancangan antarmuka menggunakan Microsoft PowerPoint.

\section{Pengembangan}

Pada tahap ini, dilakukan pembuatan program dari rancangan-rancangan yang telah dibuat. Pembuatan program yang dilakukan menggunakan bahasa pemrograman PHP, bahasa markup HTML, dan framework Laravel versi 7 serta pembuatan basis data menggunakan MySQL. Apabila pembuatan program telah selesai, kemudian dilihat oleh user dan masih ingin melakukan perubahan maka diulang ke tahap perancangan. Jika tidak ada perubahan, maka dilanjutkan ke tahap selanjutnya.

\section{Implementasi}

Pada tahap ini, dilakukan pengujian terhadap aplikasi sistem yang telah dibuat dengan metode Black Box Testing, yaitu suatu pengujian yang berfokus pada pengujian fungsionalitas.

\section{HASIL DAN PEMBAHASAN}

Pada hasil dan pembahasan akan membahas hasil dari pembuatan aplikasi Sistem Informasi Pembuatan Peraturan Perusahaan (3P) berbasis website pada DISNAKER Kota Samarinda. Adapun hasil dan pembahasan pelaksanaan sebagai berikut.

\section{A. Identifikasi Permasalahan}

Tahap ini dimulai dengan mengidentifikasi alur prosedur yang sedang berjalan saat ini, identifikasi kelemahan alur prosedur yang berjalan, dan memberikan solusi berupa analisis sistem usulan. Berdasarkan hasil wawancara dengan Kepala Seksi dan Teknis HI\&SYAKER terkait kebutuhan sistem yang akan dibangun, diperoleh activity diagram dan rumusan masalah dari alur prosedur yang sedang berjalan. Berikut adalah hasil dari kebutuhan sistem DISNAKER Kota Samarinda.

1. Analisis Alur Prosedur yang Sedang Berjalan

Setelah melakukan identifikasi alur prosedur yang sedang berjalan, didapatkan 6 aktor yaitu Perusahaan, Sekretariat, Kepala Dinas, Kepala Bidang HI\&SYAKER, Kepala Seksi HI\&SYAKER, dan Teknis. Kemudian dibuat analisis alur prosedur yang dimodelkan dengan activity diagram pada yang ditunjukan pada Gambar 2.

Gambar 2 menjelaskan alur prosedur pembuatan peraturan perusahaan pada DISNAKER Kota Samarinda secara manual. Pertama perusahaan datang menyerahkan surat permohonan, pernyataan \& draf peraturan perusahaan ke bidang Sekretariat. Selanjutnya Sekretariat akan melakukan seleksi surat permohonan yang diajukan ke bidang HI\&SYAKER. Setelah itu surat disposisi, surat permohonan, pernyataan \& draf peraturan perusahaan diberikan kepada Kepala Seksi HI\&SYAKER untuk diperiksa kelengkapan berkasnya. Jika berkas belum lengkap maka akan diinformasikan kepada perusahaan untuk melengkapi perusahaan, jika sudah lengkap maka akan diserahkan kepada Teknis untuk mempelajari dan memeriksa draf peraturan perusahaan. Setelah diperiksa dan terdapat revisi maka Teknis akan memberikan lembar revisi kepada perusahaan untuk diperbaiki, jika tidak ada revisi maka Teknis akan mencetak surat keputusan yang nantinya akan diparaf oleh Kepala Seksi HI\&SYAKER, Kepala Bidang HI\&SYAKER, dan Sekretaris setelah melalui proses memeriksa dan mempelajari hasil dari Teknis. Jika masih terdapat revisi maka akan dikembalikan ke Teknis membuat lembar revisi draf peraturan perusahaan, jika tidak ada maka Kepala Dinas akan mendatangani surat keputusan tersebut. Selanjutnya Teknis akan menerbitkan surat keputusan yang telah ditandatangani Kepala Dinas \& meresmikan peraturan perusahaan. Terakhir Teknis akan memberikan surat keputusan dan peraturan perusahaan kepada perusahaan terkait. 


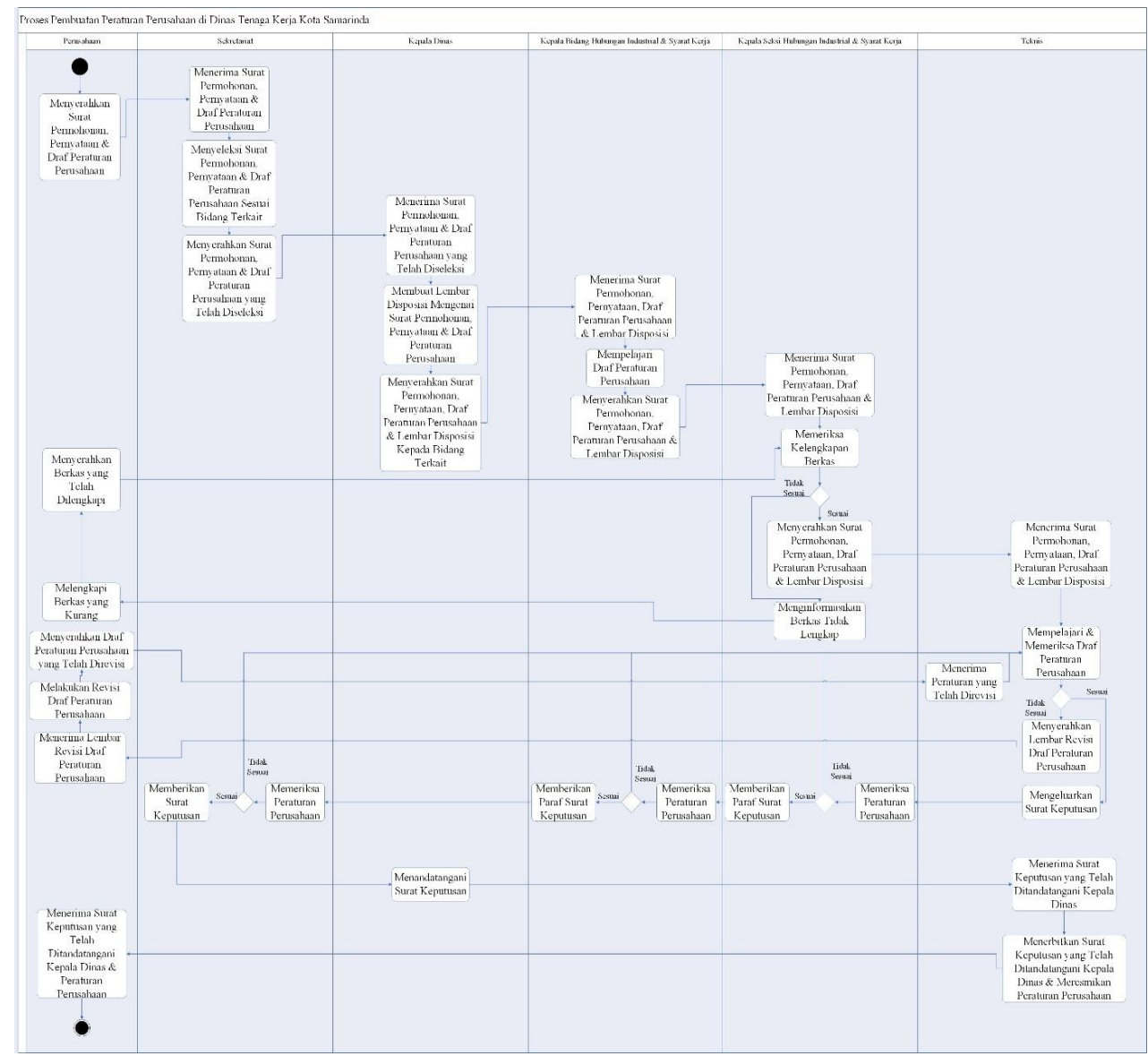

Gambar 2. Alur Prosedur Pembuatan Peraturan Perusahaan

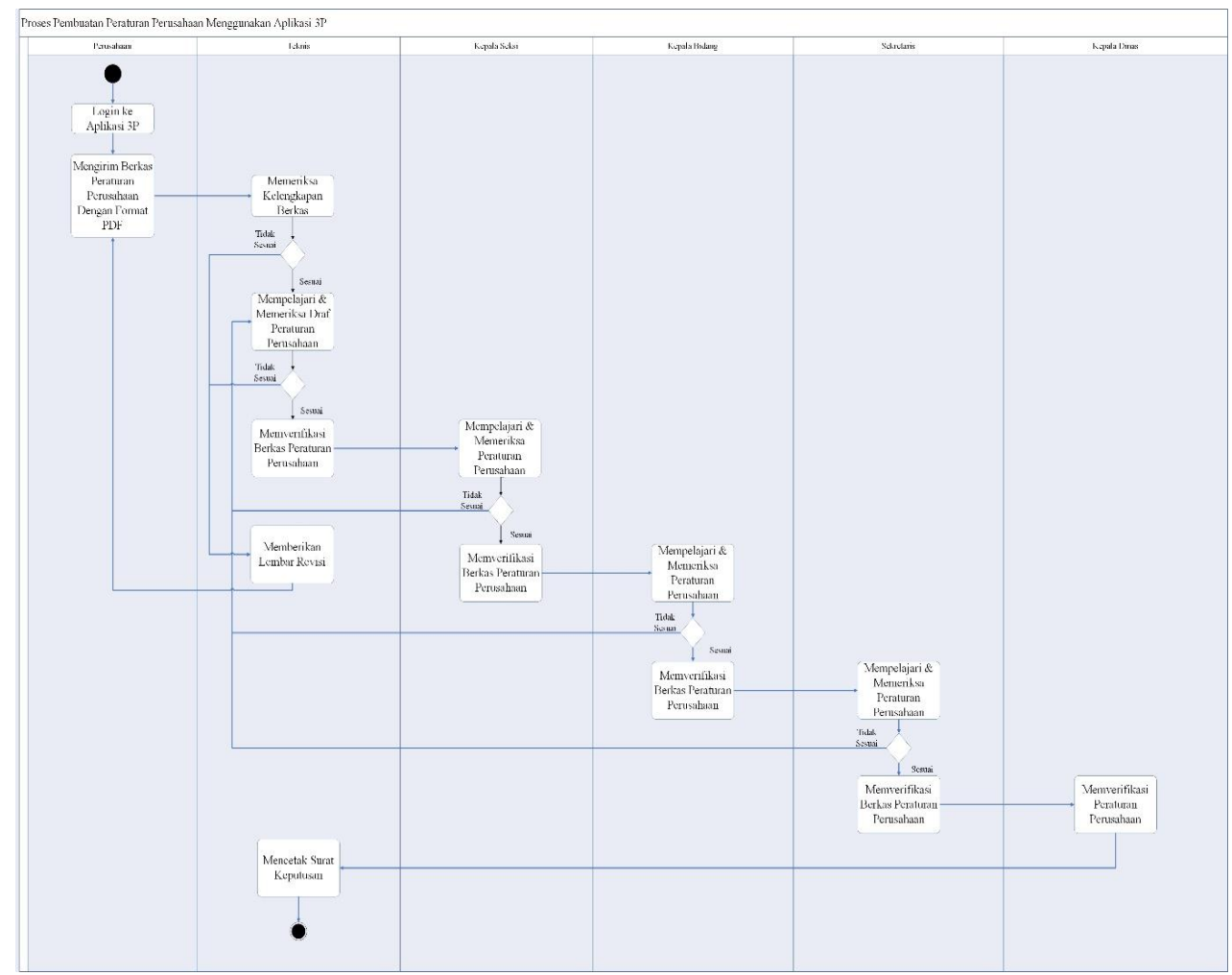

Gambar 3. Alur Aplikasi 3P 
2. Kelemahan Alur Prosedur yang Sedang Berjalan Berdasarkan analisa alur prosedur diatas, maka didapatkan kelemahan alur prosedur saat ini yaitu sebagai berikut.

a. Perusahaan harus datang ke DISNAKER untuk melakukan pembuatan peraturan perusahaan. Selain itu, perusahaan juga harus membawa surat permohonan, pernyataan, dan draf peraturan perusahaan secara manual yang pastinya akan memakan biaya cetak dari proses kelengkapan berkas maupun revisi draf peraturan perusahaan.

b. Terdapat proses yang seharusnya bisa langsung dikerjakan seperti Teknis yang langsung memeriksa

kelengkapan berkas perusahaan tanpa harus menunggu surat disposisi dari Kepala Dinas.

c. Data peraturan perusahaan yang dicatat manual juga berpotensi hilang atau terdapat human error.

\section{Solusi Pemecahan Masalah}

Solusi yang diberikan adalah dengan membuat fitur verifikasi dan mencetak surat keputusan secara online yang dapat dilakukan dimana saja oleh Teknis HI\&SYAKER. Website yang digunakan dapat dijalankan oleh perusahaan maupun pegawai DISNAKER Kota Samarinda. Perusahaan dapat mengirim berkas dan melihat berkas melalui website sedangkan pegawai DISNAKER dapat memeriksa dan memverifikasi berkas melalui website.

\section{Analisis Sistem Usulan}

Sistem informasi yang diusulkan yaitu Sistem Informasi Pembuatan Peraturan Perusahaan (3P) berbasis website. Berikut adalah proses sistem usulan setiap aktor menggunakan activity diagram yang dapat dilihat pada Gambar 3.

Gambar 3. Menjelaskan alur aplikasi 3P. Terdapat 7 aktor yang diusulkan dalam aplikasi 3P yaitu Perusahaan, Teknis, Kepala Seksi, Kepala Bidang, Sekretaris, Kepala Dinas, dan
Admin. Untuk aktor admin tidak termasuk ke dalam alur aplikasi 3P, namun aktor Admin berperan sebagai pengelola aplikasi seperti berkas-berkas peraturan perusahaan, akun dinas, dan akun perusahaan. Alur dari sistem diawali dari perusahaan login ke dalam aplikasi 3P, kemudian perusahaan mengirim berkas-berkas yang diperlukan. Berkas yang telah dikirim akan diterima oleh Teknis, selanjutnya Teknis akan memeriksa kelengkapan berkas dan mempelajari \& memeriksa draf peraturan perusahaan. Jika berkas atau draf peraturan perusahaan belum sesuai maka Teknis akan mengirimkan lembar revisi ke perusahaan terkait. Jika sudah sesuai maka Teknis akan memverifikasi berkas peraturan perusahaan, dimana berkas tersebut akan diterima oleh Kepala Seksi, Kepala Bidang, dan Sekretaris, dimana 3 aktor tersebut nantinya akan mempelajari \& memeriksa peraturan perusahaan yang sebelumnya telah diperiksa oleh Teknis. Jika masih terdapat revisi maka akan dikembalikan ke Teknis untuk membuat lembar revisi yang akan diberikan kepada perusahaan terkait. Jika sudah maka akan diverifikasi oleh Kepala Seksi, Kepala Bidang, dan Sekretaris sebagai pengganti paraf. Selanjutnya Kepala Dinas akan melakukan verifikasi peraturan perusahaan yang telah diperiksa, verifikasi tersebut akan menggantikan tanda tangan sementara sebagai persetujuan untuk pembuatan surat keputusan. Setelah itu, Teknis akan mencetak surat keputusan dari berkas yang telah diverifikasi oleh Kepala Dinas.

\section{B. Perancangan}

Pada tahap ini, dilakukan perancangan secara terperinci dari sistem usulan yang ada. Perancangan fungsionalitas dengan menggunakan Use Case Diagram, perancangan basis data menggunakan Entity Relationship Diagram, dan perancangan antarmuka sistem menggunakan Microsoft PowerPoint.

\section{Use Case Diagram}



Gambar 3. Use Case Diagram Aplikasi 3P 
Berdasarkan hasil analisis sistem usulan yang dibuat, diperoleh 7 aktor yang akan berperan dalam penggunaan Sistem informasi Pembuatan Peraturan Perusahaan (3P) seperti yang ditunjukkan pada Gambar 4. Aktor tersebut diantaranya adalah perusahaan, admin, teknis, kepala seksi, kepala bidang, sekretaris, dan kepala dinas. Berikut adalah Tabel 1 deskripsi use case diagram aplikasi 3P:

Tabel 1. Deskripsi Use Case Diagram Aplikasi 3P

\begin{tabular}{|c|c|c|c|}
\hline No & $\begin{array}{c}\text { Nama Use } \\
\text { Case }\end{array}$ & Deskripsi & Aktor \\
\hline 1 & Login & $\begin{array}{l}\text { Sebelum mengakses } \\
\text { fitur-fitur sesuai dengan } \\
\text { masing-masing hak } \\
\text { akses. Dibutuhkan email } \\
\text { dan kata sandi untuk } \\
\text { masuk ke sistem. }\end{array}$ & $\begin{array}{l}\text { Perusahaan, } \\
\text { Admin, } \\
\text { Teknis, } \\
\text { Kepala Seksi, } \\
\text { Kepala } \\
\text { Bidang, } \\
\text { Sekretaris, } \\
\text { Kepala Dinas }\end{array}$ \\
\hline 2 & $\begin{array}{l}\text { Mendaftar } \\
\text { Akun }\end{array}$ & $\begin{array}{l}\text { Sistem akan } \\
\text { menyediakan form online } \\
\text { yang berisikan nama, } \\
\text { nama perusahaan, alamat, } \\
\text { email, dan kata sandi }\end{array}$ & Perusahaan \\
\hline 3 & $\begin{array}{l}\text { Mengunggah } \\
\text { File Berkas } \\
\text { Peraturan } \\
\text { Perusahaan }\end{array}$ & $\begin{array}{l}\text { Sistem akan } \\
\text { menyediakan form online } \\
\text { yang berisikan surat } \\
\text { permohonan, draf } \\
\text { peraturan perusahaan, } \\
\text { dan keterangan. } \\
\text { Perusahaan akan memilih } \\
\text { file yang akan diunggah. }\end{array}$ & Perusahaan \\
\hline 4 & $\begin{array}{l}\text { Melihat } \\
\text { Berkas } \\
\text { Peraturan } \\
\text { Perusahaan }\end{array}$ & $\begin{array}{l}\text { Sistem akan } \\
\text { menyediakan tabel yang } \\
\text { berisikan surat } \\
\text { permohonan, draf } \\
\text { peraturan perusahaan, } \\
\text { keterangan, status, dan } \\
\text { action. }\end{array}$ & Perusahaan \\
\hline 5 & $\begin{array}{l}\text { Menghapus } \\
\text { File Berkas } \\
\text { Peraturan } \\
\text { Perusahaan } \\
\end{array}$ & $\begin{array}{l}\text { Sistem dapat menghapus } \\
\text { data berkas peraturan } \\
\text { perusahaan sesuai pilihan } \\
\text { perusahaan. }\end{array}$ & Perusahaan \\
\hline 6 & $\begin{array}{l}\text { Mengunduh } \\
\text { File Revisi } \\
\text { Berkas } \\
\text { Peraturan } \\
\text { Perusahaan }\end{array}$ & $\begin{array}{l}\text { Sistem akan } \\
\text { menampilkan tombol } \\
\text { download file revisi } \\
\text { berkas peraturan } \\
\text { perusahaan. }\end{array}$ & Perusahaan \\
\hline 7 & $\begin{array}{l}\text { Mengunggah } \\
\text { File Revisi } \\
\text { Berkas } \\
\text { Peraturan } \\
\text { Perusahaan } \\
\end{array}$ & $\begin{array}{l}\text { Sistem akan } \\
\text { menyediakan form online } \\
\text { yang berisikan revisi } \\
\text { berkas peraturan } \\
\text { perusahaan. }\end{array}$ & Perusahaan \\
\hline 8 & $\begin{array}{l}\text { Mengubah } \\
\text { Profil Akun } \\
\text { Perusahaan }\end{array}$ & $\begin{array}{l}\text { Sistem dapat merubah } \\
\text { nama, nama perusahaan, } \\
\text { alamat, email, dan kata } \\
\text { sandi. }\end{array}$ & Perusahaan \\
\hline 9 & $\begin{array}{l}\text { Menghapus } \\
\text { Berkas } \\
\text { Peraturan } \\
\text { Perusahaan }\end{array}$ & $\begin{array}{l}\text { Sistem dapat menghapus } \\
\text { berkas peraturan } \\
\text { perusahaan sesuai pilihan } \\
\text { admin maupun hapus } \\
\text { semua data berkas } \\
\text { peraturan perusahaan. }\end{array}$ & Admin \\
\hline
\end{tabular}

\begin{tabular}{|c|c|c|c|}
\hline 10 & $\begin{array}{l}\text { Menambah } \\
\text { Akun Dinas }\end{array}$ & $\begin{array}{l}\text { Sistem akan } \\
\text { menampilkan form } \\
\text { online yang berisikan } \\
\text { nama, bidang, role, dan } \\
\text { email untuk menambah } \\
\text { akun dinas. }\end{array}$ & Admin \\
\hline 11 & $\begin{array}{l}\text { Menghapus } \\
\text { Akun Dinas }\end{array}$ & $\begin{array}{l}\text { Sistem dapat menghapus } \\
\text { akun dinas sesuai pilihan } \\
\text { admin maupun } \\
\text { menghapus semua akun } \\
\text { dinas. }\end{array}$ & Admin \\
\hline 12 & $\begin{array}{l}\text { Mengedit } \\
\text { Akun Dinas }\end{array}$ & $\begin{array}{l}\text { Sistem akan } \\
\text { menampilkan form } \\
\text { online yang berisikan } \\
\text { nama, role, bidang, dan } \\
\text { email. Kemudian data } \\
\text { tersebut dapat dirubah } \\
\text { oleh admin. }\end{array}$ & Admin \\
\hline 13 & $\begin{array}{l}\text { Menghapus } \\
\text { Akun } \\
\text { Perusahaan }\end{array}$ & $\begin{array}{l}\text { Sistem dapat menghapus } \\
\text { akun perusahaan sesuai } \\
\text { pilihan admin maupun } \\
\text { menghapus akun } \\
\text { perusahaan. }\end{array}$ & Admin \\
\hline 14 & $\begin{array}{l}\text { Mencetak } \\
\text { Surat } \\
\text { Keputusan }\end{array}$ & $\begin{array}{l}\text { Sistem dapat mencetak } \\
\text { surat keputusan setelah } \\
\text { status berkas peraturan } \\
\text { perusahaan diverifikasi } \\
\text { oleh kepala dinas. }\end{array}$ & Teknis \\
\hline 15 & $\begin{array}{l}\text { Mengunggah } \\
\text { File Revisi } \\
\text { Berkas } \\
\text { Peraturan } \\
\text { Perusahaan }\end{array}$ & $\begin{array}{l}\text { Sistem akan } \\
\text { menyediakan form online } \\
\text { yang berisikan revisi draf } \\
\text { peraturan perusahaan. } \\
\text { Teknis akan memilih file } \\
\text { revisi yang akan } \\
\text { diunggah. }\end{array}$ & Teknis \\
\hline 16 & $\begin{array}{l}\text { Merevisi } \\
\text { Berkas } \\
\text { Peraturan } \\
\text { Perusahaan }\end{array}$ & $\begin{array}{l}\text { Sistem akan } \\
\text { menampilkan tombol } \\
\text { revisi berkas peraturan } \\
\text { perusahaan jika berkas } \\
\text { tersebut belum sesuai. }\end{array}$ & $\begin{array}{l}\text { Kepala Seksi, } \\
\text { Kepala } \\
\text { Bidang, } \\
\text { Sekretaris }\end{array}$ \\
\hline 17 & $\begin{array}{l}\text { Memverifikasi } \\
\text { Berkas } \\
\text { Peraturan } \\
\text { Perusahaan }\end{array}$ & $\begin{array}{l}\text { Sistem akan } \\
\text { menampilkan tombol } \\
\text { verifikasi berkas } \\
\text { peraturan perusahaan jika } \\
\text { berkas tersebut sudah } \\
\text { sesuai. }\end{array}$ & $\begin{array}{l}\text { Kepala Seksi, } \\
\text { Kepala } \\
\text { Bidang, } \\
\text { Sekretaris, } \\
\text { Kepala Dinas }\end{array}$ \\
\hline 18 & $\begin{array}{l}\text { Melihat } \\
\text { Dashboard }\end{array}$ & $\begin{array}{l}\text { Sistem akan } \\
\text { menampilkan jumlah } \\
\text { akun perusahaan, jumlah } \\
\text { akun dinas, jumlah } \\
\text { berkas yang belum } \\
\text { diverifikasi kepala dinas, } \\
\text { dan jumlah berkas yang } \\
\text { sudah diverifikasi kepala } \\
\text { dinas. } \\
\end{array}$ & $\begin{array}{l}\text { Admin, } \\
\text { Teknis, } \\
\text { Kepala Seksi, } \\
\text { Kepala } \\
\text { Bidang, } \\
\text { Sekretaris, } \\
\text { Kepala Dinas }\end{array}$ \\
\hline 19 & $\begin{array}{l}\text { Mengunduh } \\
\text { Berkas } \\
\text { Peraturan } \\
\text { Perusahaan }\end{array}$ & $\begin{array}{l}\text { Sistem akan } \\
\text { menampilkan tombol } \\
\text { download file berkas } \\
\text { peraturan perusahaan. }\end{array}$ & $\begin{array}{l}\text { Admin, } \\
\text { Teknis, } \\
\text { Kepala Seksi, } \\
\text { Kepala } \\
\text { Bidang, } \\
\text { Sekretaris, } \\
\text { Kepala Dinas }\end{array}$ \\
\hline
\end{tabular}




\begin{tabular}{lll}
\hline & & \\
& & $\begin{array}{l}\text { Admin, } \\
\text { Teknis, }\end{array}$ \\
Kengubah & Kepala Seksi, \\
Profil Akun & Sistem dapat merubah & Kepala \\
Dinas & nama dan kata sandi. & Bidang, \\
& & Sekretaris, \\
& & Kepala Dinas \\
\hline
\end{tabular}

Tabel 1 merupakan deskripsi Use Case Diagram aplikasi 3P. Berdasarkan Use Case Diagram didapatkan 20 use case dan 7 aktor yang akan berperan dalam penggunaan Sistem Informasi Pembuatan Peraturan Perusahaan (3P). Tabel ini menjelaskan deskripsi untuk setiap use case yang akan diperankan oleh setiap aktor.

\section{Entity Relationship Diagram}

Diagram relasi antar entitas untuk setiap tabel yang terdapat pada basis data Sistem Informasi Pembuatan Peraturan Perusahaan (3P) disajikan pada Gambar 5. Terdapat 4 entitas kuat yaitu user, bidang, berkas, dan akun Perusahaan. Relasi untuk entitas diatas dapat dijabarkan sebagai berikut.

a. Satu bidang dapat memiliki banyak user.

b. Satu user dapat memverifikasi banyak berkas.

c. Satu perusahaan dapat mengirim banyak berkas.

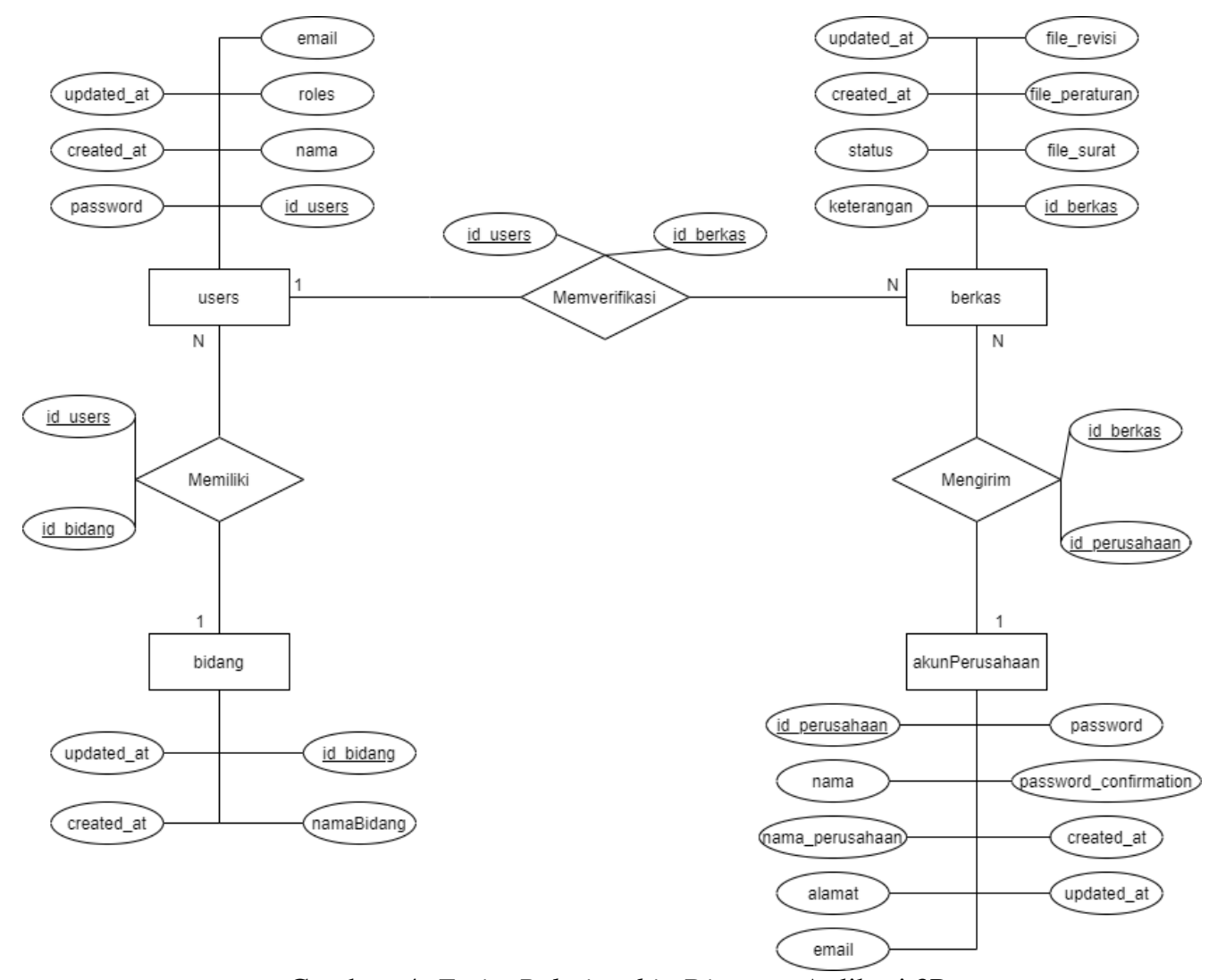

Gambar 4. Entity Relationship Diagram Aplikasi 3P

3. Mockup Antarmuka Aplikasi 3P

Berikut merupakan desain tampilan dari aplikasi 3P yang dijadikan acuan dalam membuat aplikasi Sistem Informasi Pembuatan peraturan perusahaan (3P) DISNAKER Kota Samarinda.

Gambar 6 merupakan desain tampilan halaman kirim berkas peraturan perusahaan. Perusahaan mengunggah file surat permohonan dan draf peraturan perusahaan dengan format PDF serta memberikan keterangan.

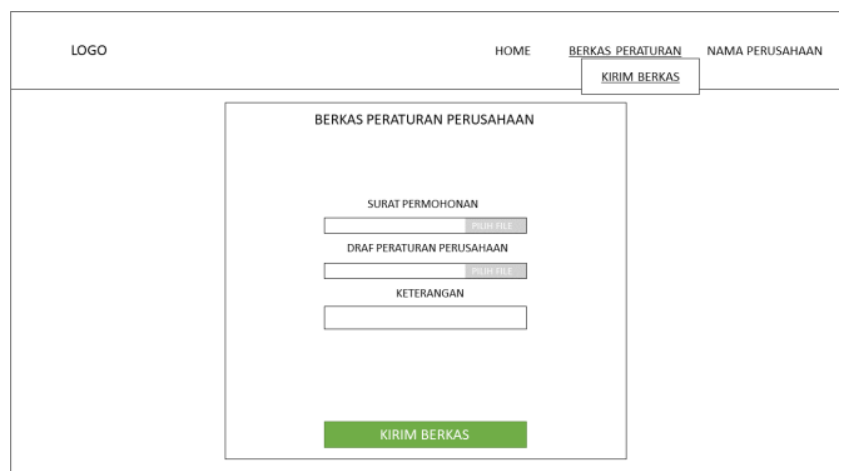

Gambar 5. Desain Tampilan Halaman Kirim Berkas Peraturan Perusahaan 


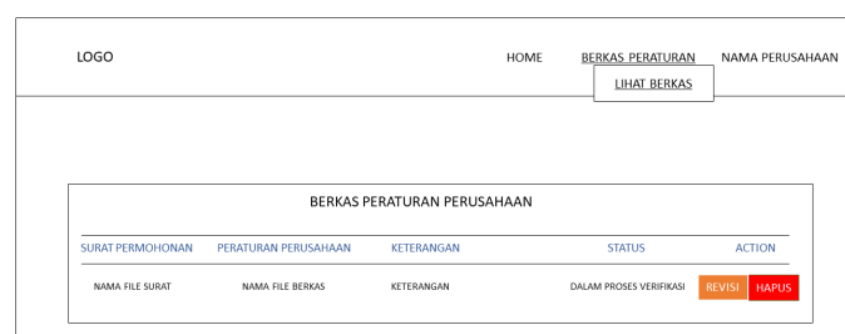

Gambar 6. Desain Tampilan Halaman Lihat Berkas Peraturan Perusahaan

Gambar 7 merupakan desain tampilan halaman lihat berkas peraturan perusahaan. Perusahaan dapat melihat berkas yang mereka kirim sehingga perusahaan dapat melihat progres peraturan perusahaan melalui status, jika status telah diverfikasi oleh kepala dinas maka perusahaan sudah bisa mengambil surat keputusan dan peraturan perusahaan yang sudah diresmikan.

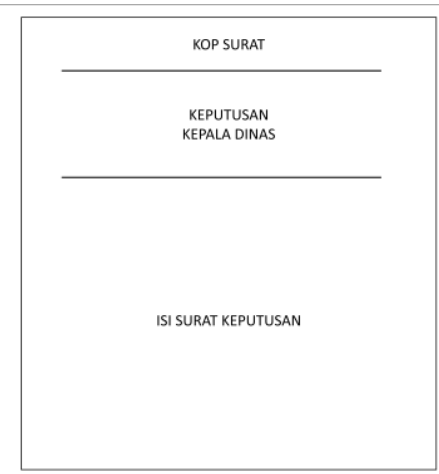

Gambar 7. Desain Tampilan Halaman Cetak Surat Keputusan

Gambar 8 merupakan desain tampilan halaman cetak surat keputusan. Pada halaman ini teknis dapat langsung mencetak surat keputusan jika terkoneksi oleh printer atau dapat save as PDF untuk menyimpan file surat keputusan.

\section{Implementasi}

Pada tahap ini, dilakukan pembuatan program dari perancangan yang telah dibuat. Pembuatan program menggunakan bahasa pemrograman PHP, bahasa markup HTML, framework Laravel versi 7, dan basis data menggunakan MySQL. Berikut merupakan hasil dari pengkodean program sesuai dengan rancangan yang telah dibuat.

Gambar 9 merupakan tampilan halaman kirim berkas peraturan perusahaan. Halaman ini digunakan Perusahaan untuk mengirim berkas peraturan perusahaan yang ingin disahkan. Berkas-berkas yang diperlukan yaitu surat permohonan (termasuk pernyataan) dan draf peraturan perusahaan, selain itu keterangan perlu diisi dengan peraturan perusahaan terkait.

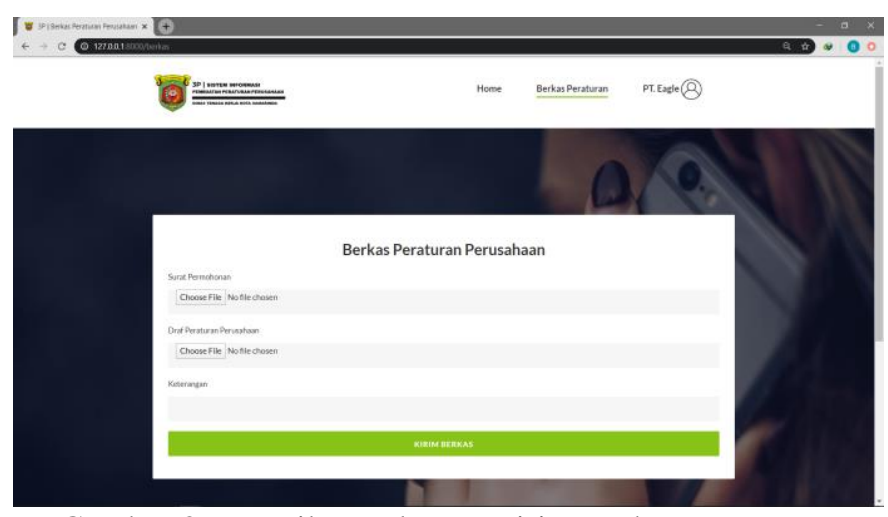

Gambar 8. Tampilan Halaman Kirim Berkas Peraturan Perusahaan

Gambar 10 merupakan tampilan halaman lihat berkas peraturan perusahaan. Halaman ini akan digunakan Perusahaan untuk melihat status berkas peraturan perusahaan. Jika status "Telah Diverifikasi Kepala Dinas" maka perusahaan dapat mengambil peraturan perusahaan yang telah disahkan di DISNAKER.

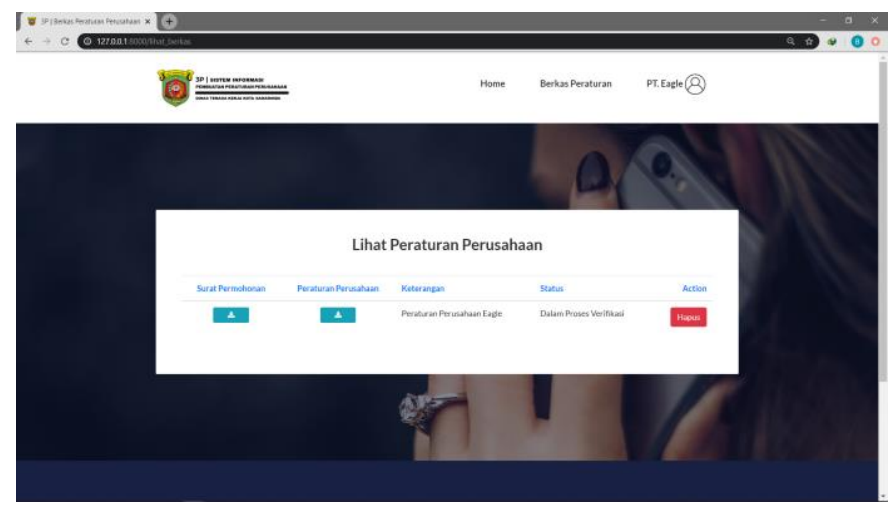

Gambar 9. Tampilan Halaman Lihat Berkas Peraturan Perusahaan

Gambar 11 merupakan tampilan halaman cetak surat keputusan. Halaman ini akan digunakan oleh Teknis untuk mencetak surat keputusan perusahaan sesuai dengan berkas peraturan perusahaan terkait yang telah diverifikasi kepala dinas.

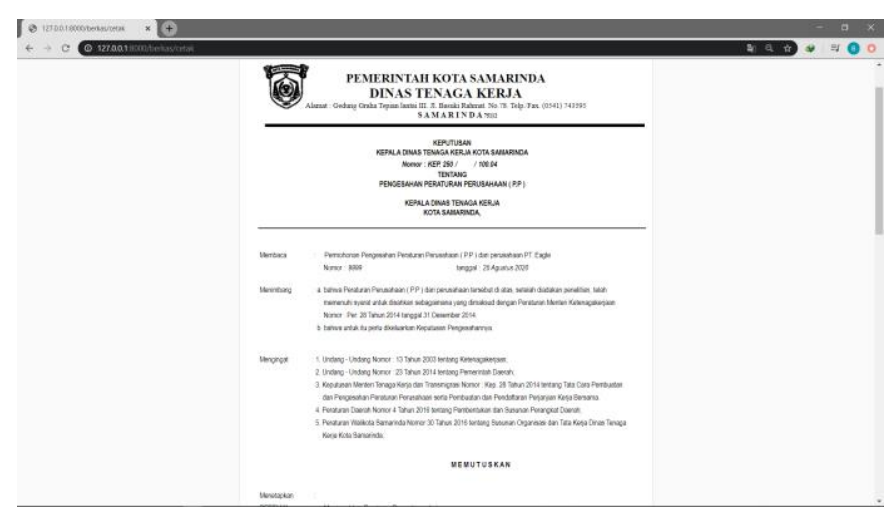

Gambar 10. Tampilan Halaman Cetak Surat Keputusan 
D. Uji Coba

Pada tahap ini, dilakukan pengujian terhadap aplikasi 3P yang telah dibuat dengan metode Black Box Testing. Metode blacbox testing merupakan pengujian tanpa melihat source code program. Pengujian aplikasi 3P telah dilakukan oleh Teknis, Kepala Seksi, dan Sekretaris DISNAKER Kota Samarinda. Berikut adalah penjelasan mengenai hasil pengujian yang disajikan pada Tabel 2 .

\section{Tabel 2. Hasil Pengujian Aplikasi 3P Menggunakan Black Box Testing}

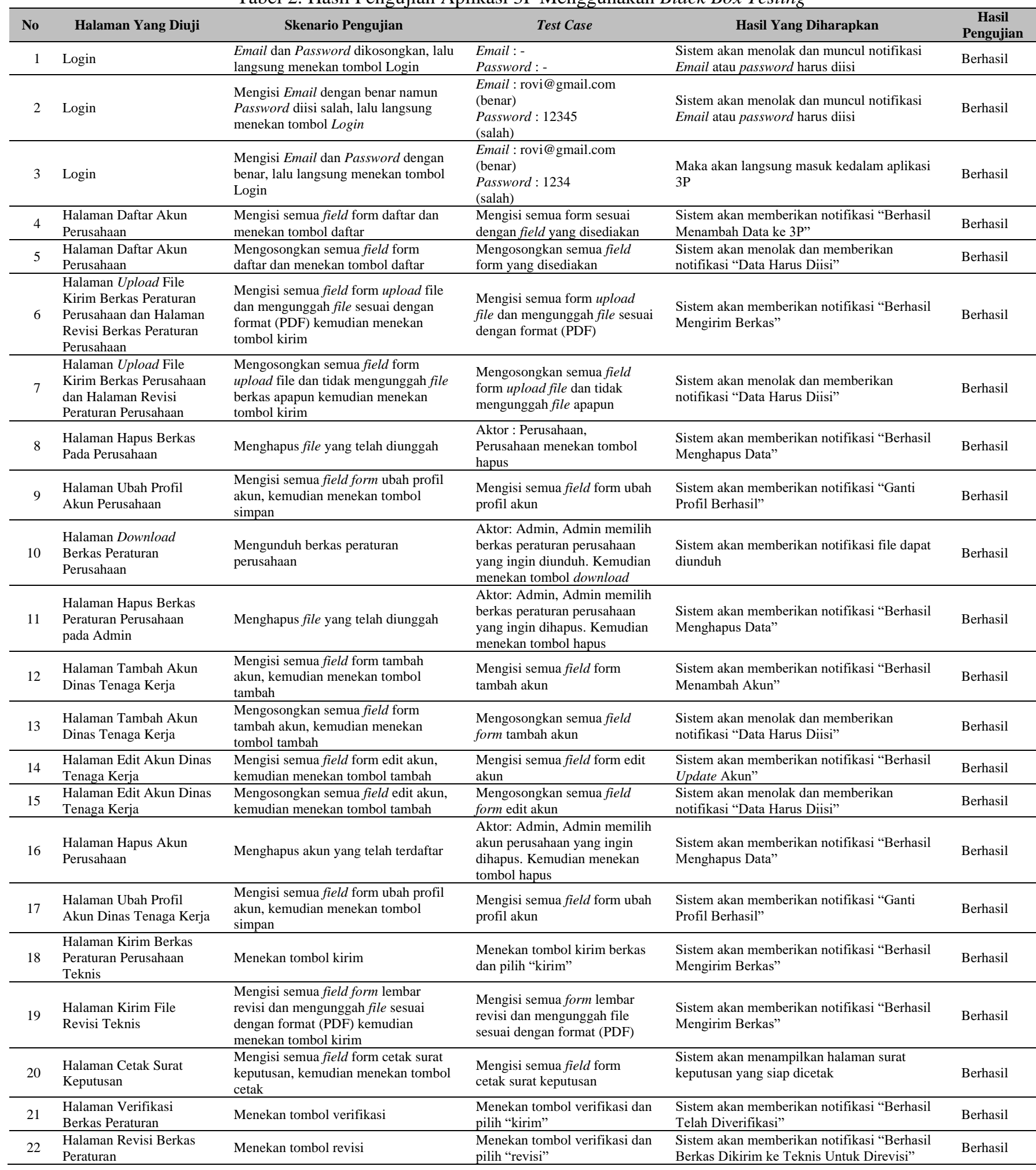


Tabel 2 merupakan hasil pengujian aplikasi 3P menggunakan blackbox testing. Hasil pengujian ini berdasarkan use case diagram aplikasi 3P yang telah dibuat tanpa melihat source code program. Tabel ini menjelaskan skenario pengujian yang diuji menggunakan kasus tes dengan hasil yang diharapkan pengguna aplikasi 3P. Pengujian aplikasi 3P dilakukan bersama Teknis, Kepala Seksi, dan Sekretaris DISNAKER Kota Samarinda dengan hasil pengujian berhasil pada setiap skenario pengujian.

\section{KESIMPULAN}

Berdasarkan penelitian merancang dan membangun Sistem Informasi Pembuatan Peraturan Perusahaan (3P) berbasis website dengan menggunakan Rapid Application Development (RAD). Maka dapat disimpulkan, sistem yang dibangun menggunakan metode RAD telah sesuai dengan usulan sistem yang dirancang dimana terdapat 20 Use Case Diagram yang telah diuji menggunakan black box testing dengan hasil pengujian berhasil pada setiap skenario pengujian sebagaimana dapat dilihat pada Tabel 2. Dengan pengujian yang telah dilakukan bersama Sekretaris, Kepala Seksi, dan Teknis DISNAKER didapatkan hasil bahwa sistem ini dapat membantu kinerja DISNAKER dalam hal membantu masyarakat membuat peraturan perusahaan secara online.

\section{REFERENSI}

[1] Nasir, A. \& Oktari, R. (2011). Pengaruh Pemanfaatan Teknologi Informasi dan Pengendalian Intern Terhadap Kinerja Instansi Pemerintah. Jurnal Ekonomi, Vol. 19(2).
[2] Budiman, H. (2017). Peran Teknologi Informasi dan Komunikasi Dalam Pendidikan. Al-Tadzkiyyah: Jurnal Pendidikan Islam, Vol. 8(1) p. 31-43.

[3] Noviari, N. (2007). Pengaruh Teknologi Informasi Terhadap Perkembangan Akuntansi. Jurnal Ilmiah Akuntansi dan Bisnis, Vol. 2(1).

[4] Kissflow (2020). Rapid Application Development (RAD): Changing How Developers Work [Online]. Diakses dari: https://kissflow.com/rad/rapid-applicationdevelopment/ pada tanggal 2 Februari 2021.

[5] Amalia, R. \& Huda, N. (2020). Sistem Informasi Pengarsipan Surat Masuk dan Surat Masuk dan Surat Keluar Pada Dinas Tenaga Kerja dan Transmigrasi kabupaten Musi Banyuasin. Jurnal Media Informatika Budidarma, Vol. 4(2), pp. 363-368.

[6] Ja'ng, S. (2016). Susunan Organisasi Dan Tata Kerja Dinas Tenaga Kerja Kota Samarinda. Samarinda.

[7] Subianto (2020). Penerapan Metode Rapid Application Development dalam Perancangan Sistem Informasi Pendataan. Jurnal INFOKAM, Vol. 16(1).

[8] Object Management Group UML (2017). About The Unified Modeling Language Specification Version 2.5.1 [Online]. Diakses dari: https://www.omg.org/spec/ UML/About-UML/.

[9] Chen, P.P. (2002). Entity-Relationship Modeling: Historical Events, Future Trends, and Lessons Learned. Software Pioneer, pp. 296-310. 